\title{
A DNA POLYMERASE ISOLATED FROM BOVINE SPERMATOZOA
}

\author{
N. B. HECHT \\ Department of Biology, Tufts University, \\ Medford, Massachusetts 01255, U.S.A.
}

(Received 9th February 1974)

\begin{abstract}
Summary. A DNA-dependent DNA polymerase has been solubilized by sonication from mature bovine spermatozoa. The activity was characterized by the following enzymatic and physical properties: (1) it required an activated DNA template, $\mathrm{Mg}^{++}$and all four deoxyribonucleoside triphosphates for maximal activity, (2) it was stimulated by salt, (3) it was inhibited by low concentrations of ethidium bromide, and (4) it had an estimated mol. wt of 150,000 . A comparison of this activity with DNA polymerases isolated from subcellular fractions of bovine and murine cells suggests that this activity may be of mitochondrial origin.
\end{abstract}

\section{INTRODUCTION}

The timing of DNA synthesis during spermatogenesis has been well characterized by many autoradiographic studies (Clermont \& Leblond, 1953; Oakberg, 1956, 1957; Clermont \& Perey, 1957). In general, most of the DNA synthesis during spermatogenesis is completed by the primary spermatocyte stage. By contrast, the enzymatic basis for DNA metabolism in the mammalian testis is not well understood. Calvin, Kosto \& Williams-Ashman (1967) have described a DNA polymerase activity isolated from rat testis and Katz \& Hecht (1973) and Hecht (1973) have reported the existence of several different DNA polymerase activities isolated from total testis extracts of the mouse. Nothing is known about the DNA synthetic capacity of individual testicular cell types.

In this communication, we report the existence of a DNA polymerase isolated from mature bovine spermatozoa and present a characterization of some of its properties.

\section{MATERIALS AND METHODS}

\section{Preparation of DNA polymerase extract}

Frozen bull semen $\left(8 \times 10^{7}\right.$ spermatozoa $\left./ \mathrm{ml}\right)$ was centrifuged at $5000 \mathrm{~g}$ for $10 \mathrm{~min}$ and resuspended in wash buffer $(0.25 \mathrm{~m}$-sucrose, $0.15 \mathrm{M}-\mathrm{NaCl}$, $0.01 \mathrm{M}$-tris, $\mathrm{pH} 7.9$ ). The wash was repeated three times. All further procedures were performed at $4^{\circ} \mathrm{C}$. The final pellet was resuspended in the wash buffer, layered over $1.8 \mathrm{M}$-sucrose (dissolved in wash buffer), and centrifuged at $13,000 \mathrm{~g}$ 
for $30 \mathrm{~min}$ in a Sorvall HB-4 rotor. The pellet was resuspended in extraction buffer $(0.02 \mathrm{M}$-tris, pH 8.1, 0.05 $\mathrm{M}-\mathrm{NaCl}, 0.003 \mathrm{M}$-mercaptoethanol, $0.001 \mathrm{M}$ EDTA, $0.125 \mathrm{M}-\left(\mathrm{NH}_{4}\right)_{2} \mathrm{SO}_{4}, 10 \mu \mathrm{g} / \mathrm{ml}$ soybean trypsin inhibitor, and $20 \%$ ethylene glycol). The DNA polymerase activity was solubilized by sonicating the spermatozoa for $100 \mathrm{sec}$ at a setting of 4 in a Branson Sonifier (model $\mathrm{W} 185$ ). The extract was clarified by centrifugation at $27,000 \mathrm{~g}$ for $30 \mathrm{~min}$ in a Sorval SS-34 rotor. The supernatant contained 85 to $95 \%$ of the total recoverable activity.

\section{Assay of DNA polymerase}

The DNA polymerase activity was measured by a modification of a method previously described (Hecht, 1973). Incubation was carried out at $37^{\circ} \mathrm{C}$ for $60 \mathrm{~min}$. The standard incubation mixture $(0.3 \mathrm{ml})$ contained $25 \mu \mathrm{mol}$ glycine$\mathrm{NaOH}$ buffer at $\mathrm{pH} 9 \cdot 2,2.5 \mu \mathrm{mol} \mathrm{MgCl}_{2}, 3 \mu \mathrm{mol}$ mercaptoethanol, $5 \mu \mathrm{mol}$ $\mathrm{KCl}, 160 \mathrm{nmol}$ activated calf thymus DNA, $10 \mathrm{nmol}$ each of dCTP, dATP and dGTP, $1 \mathrm{nmol}\left[{ }^{3} \mathrm{H}\right] \mathrm{TTP}(1000 \mathrm{ct} / \mathrm{min} / \mathrm{pmol})$ and enzyme. The calf thymus DNA was activated by the method of Aposhian \& Kornberg (1962). The reaction was linear for at least the $2 \mathrm{hr}$ during which it was measured. After incubation, the tubes were placed in ice and the reaction was stopped by the addition of $0.5 \mathrm{ml}$ cold $1 \mathrm{~N}$-perchloric acid containing $0.02 \mathrm{M}$-sodium pyrophosphate. The precipitates were collected on glass fibre filters (Whatman GF/A) and washed with $10 \mathrm{ml}$ of $5 \%$ perchloric acid containing $0.02 \mathrm{M}$ sodium pyrophosphate and $10 \mathrm{ml}$ of $95 \%$ ethanol. The filters were dried and counted in a liquid scintillation counter.

Activity was measured at DNA polymerase levels where nucleotide incorporation was proportional to enzyme concentration. Therefore, in terms of the total amount of nucleotide incorporated, the values for the calf thymus DNAprimed assay are approximately four times the amount of $\left[{ }^{3} \mathrm{H}\right]$ TMP incorporated into acid insoluble form.

\section{Chromatography}

Whatman phosphocellulose (P-11: Reeve Angel) was washed by the method

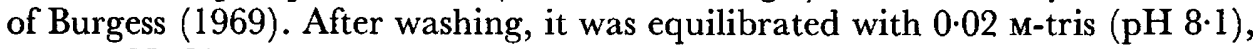
$0.05 \mathrm{M}-\mathrm{NaCl}, 0.003 \mathrm{~m}$-mercaptoethanol, $0.001 \mathrm{~m}$-EDTA and $20 \%$ ethylene glycol. Phosphocellulose columns $(1 \mathrm{~cm} \times 15 \mathrm{~cm})$ were poured and washed overnight by gravity. After crude enzyme extract was loaded, the columns were washed with equilibration buffer and eluted with a continuous gradient from $0.05 \mathrm{M}-\mathrm{KCl}$ to $1.0 \mathrm{M}-\mathrm{KCl}$ in equilibration buffer.

Sephadex G-200 (Pharmacia) was equilibrated with extraction buffer and columns $0.8 \mathrm{~cm}$ in diameter and $30 \mathrm{~cm}$ long were prepared. The protein was eluted from the column with extraction buffer. The column was calibrated using lactic dehydrogenase, $E$. coli alkaline phosphatase, bovine serum albumin, and cytochrome $\mathrm{C}$ as reference proteins. The void volume $\left(\mathrm{V}_{0}\right)$ was determined using dextran blue dye.

\section{Sucrose gradient centrifugation}

Sedimentation coefficients were determined using the method of Martin 
\& Ames (1961). Aliquots from the phosphocellulose peak were diluted and layered over 5 to $20 \%$ sucrose gradients (sucrose dissolved in $0.02 \mathrm{M}$-tris pH 8.1, 0.05 M-NaCl, 0.003 M-mercaptoethanol, 0.001 M-EDTA, 20\% ethylene glycol) and centrifuged for $18 \mathrm{hr}$ at $216,000 \mathrm{~g}$ at $4^{\circ} \mathrm{C}$ in a $\mathrm{SW} 65$ rotor in a Beckman L2-65 centrifuge.

\section{RESULTS}

A DNA polymerase activity was solubilized from a washed preparation of mature bull spermatozoa by sonication. The optimal sonication conditions of $100 \mathrm{sec}$ at a setting of 4 released between 85 and $95 \%$ of the total DNA polymerase activity to the supernatant fraction. Reduced sonication time solubilized less activity. In the absence of sonication, no DNA polymerase was detectable. The crude activity was labile; the presence of both trypsin inhibitor and ethy-

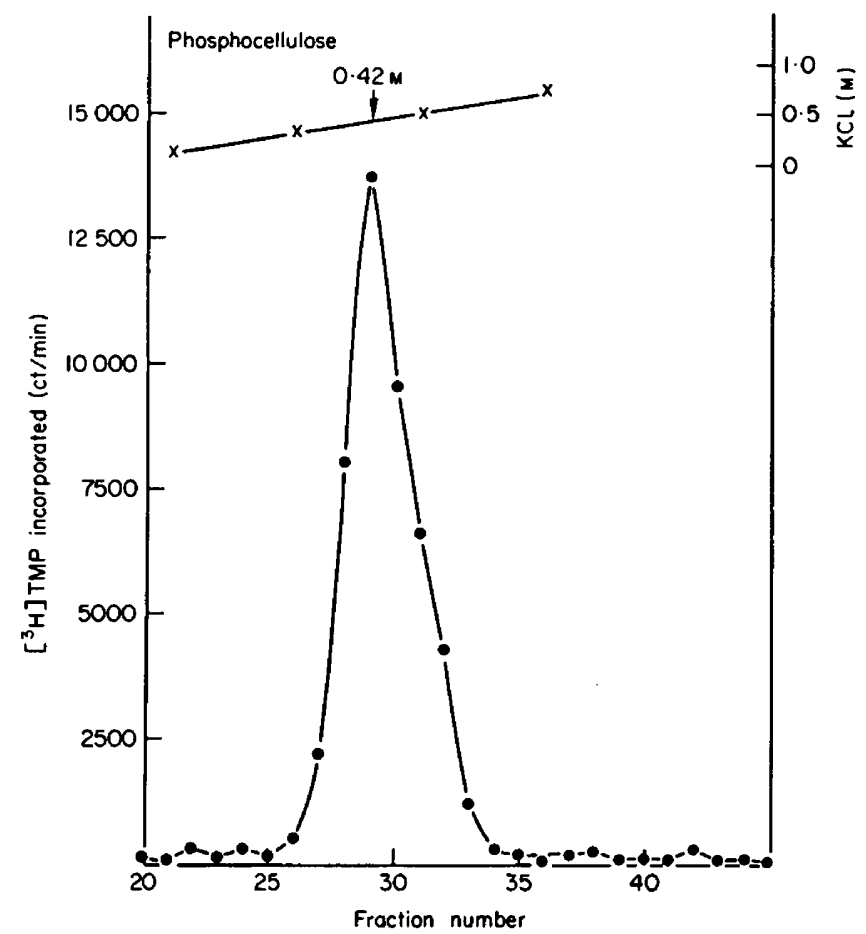

TEXT-FIG. 1. Phosphocellulose chromatography of an extract of bull spermatozoa. A sonicated extract from $40 \mathrm{ml}$ washed bull spermatozoa $\left(3 \times 10^{9}\right.$ spermatozoa) was prepared and $20 \mathrm{ml}(0.2 \mathrm{mg} / \mathrm{ml})$ was loaded onto a column $(1 \mathrm{~cm} \times 15 \mathrm{~cm})$ at a flow rate of $4 \mathrm{ml} / \mathrm{hr}$. The column was washed with $40 \mathrm{ml}$ equilibration buffer and eluted with a continuous gradient from $0.05 \mathrm{~m}-\mathrm{KGl}$ to $1.0 \mathrm{M}-\mathrm{KGl}$ in equilibration buffer. Fractions $(0.7 \mathrm{ml})$ were collected at a flow rate of $4 \mathrm{ml} / \mathrm{hr}$ directly into bovine serum albumin $(1 \mathrm{mg} / \mathrm{ml}$ final concentration). Aliquots $(0.02 \mathrm{ml})$ were assayed for DNA polymerase activity. An extract of $3 \times 10^{9}$ spermatozoa yielded enzyme activity capable of synthesizing 2000 to $4000 \mathrm{pmol}$ DNA. It was not possible to calculate specific activities due to difficulty in measuring total sperm protein and due to the presence of the bovine serum albumin used to stabilize the phosphocellulose fractions. Attempts to measure enzyme activity from phosphocellulose columns in the absence of bovine serum albumin gave variable and much reduced yields. 
lene glycol being essential for its stabilization. In their absence, the recovery of enzyme activity was reduced and variable.

The crude supernatant was chromatographed on phosphocellulose. One major peak of activity eluted at $0.42 \mathrm{M}-\mathrm{KGl}$ (Text-fig. 1). All further investigations were carried out using pooled fractions obtained from phosphocellulose. Bovine serum albumin, at a final concentration of $1 \mathrm{mg} / \mathrm{ml}$, was used to stabilize the activity and the polymerase was stored under liquid nitrogen.

\section{Properties of the sperm DNA polymerase}

The DNA polymerase activity catalyzes the synthesis of a product that is totally digested by DNase and resistant to RNase. The activity required $\mathrm{Mg}^{++}$, a DNA template, mercaptoethanol, and showed maximal activity in the presence of all four deoxyribonucleoside triphosphates. The optimal $\mathrm{pH}$ for assay was $\mathrm{pH} 9 \cdot 2$ (glycine-NaOH buffer) and the activity preferentially utilized DNase-treated double-stranded DNA (activated DNA). Native or single-stranded DNA yielded only 1 to $3 \%$ of the activity seen with activated DNA. If primer was omitted, no DNA synthesis was observed. The optimal assay temperature was $37^{\circ} \mathrm{C}$, the activity showing $85 \%$ of maximum at $31^{\circ} \mathrm{C}$ and $74 \%$ of maximum at $46^{\circ} \mathrm{C}$. The activity had a requirement for $\mathrm{Mg}^{++}$, maximal activity being obtained at 8 to $14 \mathrm{~mm}-\mathrm{Mg}^{++}$. The sperm DNA polymerase required the presence of four deoxyribonucleoside triphosphates for maximal activity. As with most eucaryotic DNA polymerases (Sedwick, Wang \& Korn, 1972), however, the activity demonstrated substantial incorporation

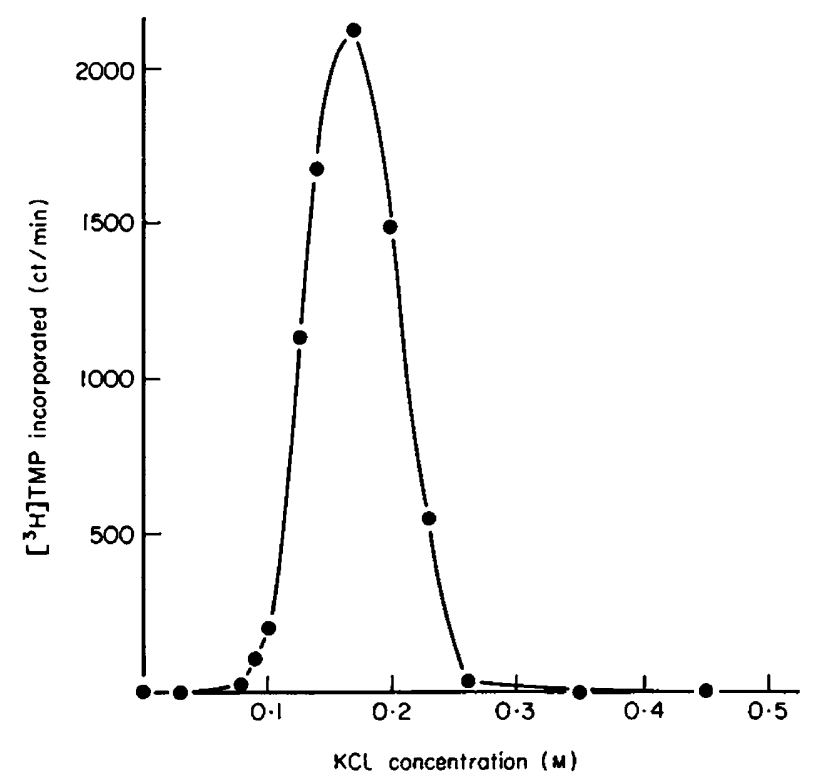

Text-fig. 2. The effect of $\mathrm{KGl}$ on bull sperm DNA polymerase. The phosphocellulose fraction (tubes 28 to 30 from Text-fig. 1) was assayed for DNA polymerase activity. The reaction mixture and conditions of incubation were as described except that the final KCl concentration was varied. 
(36\% of maximum) when only TTP was present. Similar levels of incorporation were observed using dATP, dGTP or dCTP.

The effect of increasing salt concentration is seen in Text-fig. 2. The optimal concentration of salt required for activity was $0.15 \mathrm{M}$ to $0.017 \mathrm{M}$. This stimulation was not specific for $\mathrm{KGl}$ since identical results were obtained with $\mathrm{NaCl}$ or $\mathrm{NH}_{4}$ Cl.

Molecular weight. The molecular weight distribution of the DNA polymerase activity was estimated by its elution volume on gel filtration (Text-fig. 3 ) by a modification of the method of Andrews (1965) and by sedimentation in sucrose gradients (Text-fig. 4) by the method of Martin \& Ames (1961). For gel filtrations on Sephadex G-200, ratios of the elution volume to the void volume, $\mathrm{V}_{\mathrm{e}}: \mathrm{V}_{\mathrm{o}}$, varied from 1.34 to 1.41 in four determinations. Lactic dehydrogenase, a protein of mol. wt estimated to be 150,000 (Klotz \& Darnall, 1969), had a $\mathrm{V}_{\mathrm{e}}: \mathrm{V}_{\mathrm{o}}$ of 1.41 when analysed under identical conditions. The sperm DNA polymerase and lactic dehydrogenase had similar elution profiles when analysed separately or mixed. Assuming a globular structure, the sperm DNA polymerase has an estimated mol. wt of about 150,000. Text-figure 4 shows the sedimentation profile of the DNA polymerase in a 5 to $20 \%$ sucrose gradient. Using $E$. coli alkaline phosphatase $\left(\mathrm{S}_{20, \mathrm{w}}=6.3 ; \mathrm{mol}\right.$. wt 80,000$)$ and catalase $\left(S_{20, \mathrm{w}}=11 \cdot 3\right.$; mol. wt 232,000$)$ as reference markers, a sedimentation coefficient of $8 \cdot 8 \mathrm{~S}$ and a calculated mol. wt of 152,000 was obtained for the pre-

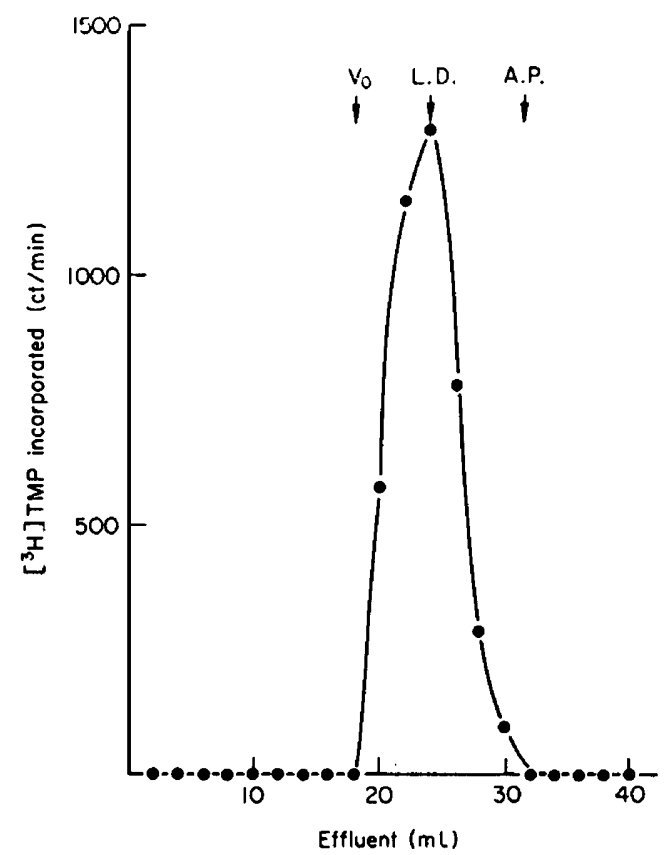

TEXT-FIG. 3. Gel filtration of the bull sperm DNA polymerase. One $\mathrm{ml}$ of the phosphocellulose fraction was applied to a Sephadex G-200 column $(0.8 \mathrm{~cm} \times 30 \mathrm{~cm})$ that had been equilibrated with extraction buffer. Fractions $(2 \mathrm{ml})$ were collected at a flow rate of $4 \mathrm{ml} /$ $\mathrm{hr}$ and $0.05 \mathrm{ml}$ samples were assayed for DNA polymerase. The columns were calibrated with blue dextran (Vo), lactic dehydrogenase (L.D.), E. coli alkaline phosphatase (A.P.), bovine serum albumin, and horse heart cytochrome $G$. 


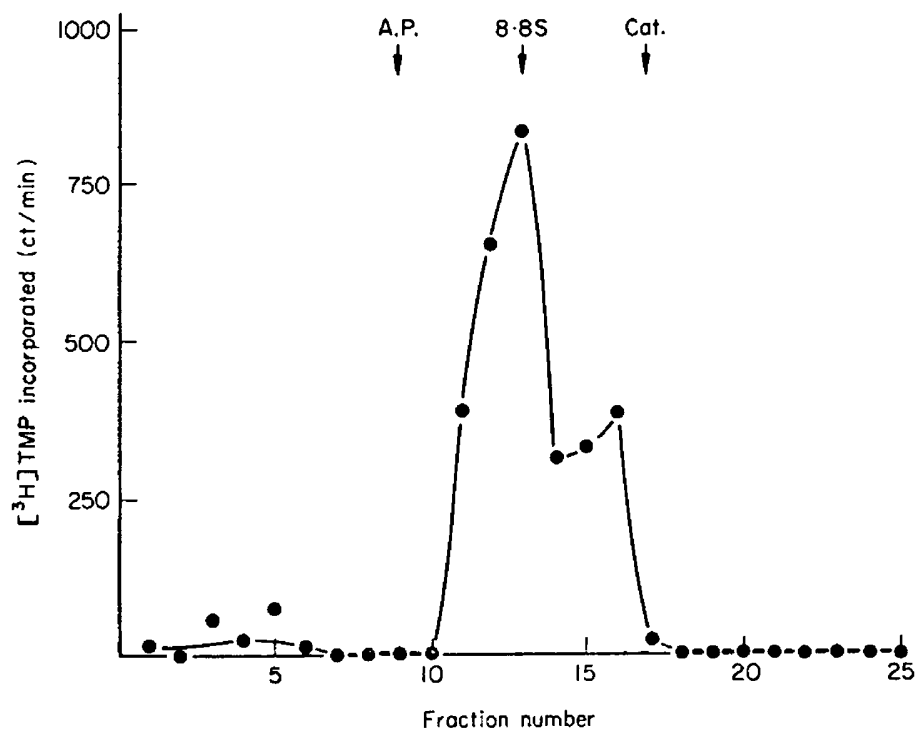

TeXT-Fig. 4. Sucrose gradient centrifugation of the bull sperm DNA polymerase. The centrifugation was performed as described in 'Materials and Methods'. Sedimentation was to the right. Gradients were fractionated into twenty-five samples of $0.2 \mathrm{ml}$. Each sample was assayed for DNA polymerase. The arrow marked A.P. indicates the position of alkaline phosphatase $\left(S_{20, w}=6 \cdot 3\right)$; the arrow marked Cat. indicates the position of catalase $\left(\mathbf{S}_{20, w}=11 \cdot 3\right)$. This figure is representative of seven determinations.

dominant DNA polymerase activity. The more rapidly sedimenting shoulder to this main peak was variable in amount and may represent an aggregation product. Similar results were obtained when mouse mitochondrial DNA polymerase activity was analysed by sucrose gradients in low salt (Hecht, 1973). The presence of ethylene glycol in the gradients was necessary to obtain recoveries of the loaded activity of $90 \%$ or better.

Inhibition by ethidium bromide. Ethidium bromide is an effective inhibitor of some DNA polymerases. Table 1 shows a comparison of the ethidium bromide

Table 1. Inhibition of bovine DNA polymerases by ethidium bromide

\begin{tabular}{|c|c|c|c|}
\hline \multirow[b]{2}{*}{$\begin{array}{l}\text { Final concentration of } \\
\text { ethidium bromide }(\mu \mathrm{M})\end{array}$} & \multicolumn{3}{|c|}{$\%$ Activity remaining } \\
\hline & $\begin{array}{c}\text { Sperm } \\
\text { polymerase }\end{array}$ & $\begin{array}{c}\text { Mitochondrial } \\
\text { polymerase }\end{array}$ & $\begin{array}{c}\text { Nuclear } \\
\text { polymerase }\end{array}$ \\
\hline $\begin{array}{r}0 \\
4 \\
8 \\
16 \\
32\end{array}$ & $\begin{array}{r}100 \\
51 \\
31 \\
22 \\
11\end{array}$ & $\begin{array}{r}100 \\
50 \\
33 \\
18 \\
8\end{array}$ & $\begin{array}{r}100 \\
81 \\
93 \\
77 \\
67\end{array}$ \\
\hline
\end{tabular}

Freshly prepared ethidium bromide $\left(2.5 \times 10^{-4} \mathrm{M}\right.$-stock) was added at the concentrations shown to the reaction mixture previously described. All enzymes were previously purified by phosphocellulose chromatography. In the experiment reported above, control values were $12,766 \mathrm{ct} / \mathrm{min}\left[{ }^{3} \mathrm{H}\right] \mathrm{TMP}$ incorporated $/ 20 \mu l$ sperm enzyme, $22,614 \mathrm{ct} / \mathrm{min}\left[{ }^{3} \mathrm{H}\right] \mathrm{TMP}$ incorporated $/ 20 \mu l$ mitochondrial enzyme and $23,610 \mathrm{ct} / \mathrm{min}\left[{ }^{3} \mathrm{H}\right] \mathrm{TMP}$ incorporated $/ 20 \mu 1$ low mol. wt chromatin-bound nuclear enzyme. Similar amounts of inhibition were obtained in assays in which the amount of enzyme fraction was varied several fold. 
Table 2. Distribution of bull sperm DNA polymerase activity on discontinuous sucrose gradients after sonication

\begin{tabular}{c|c|c|c}
\hline $\begin{array}{c}\text { Time of sonication } \\
(\text { sec })\end{array}$ & $\begin{array}{c}\text { Soluble fraction } \\
(\%)\end{array}$ & $\begin{array}{c}\text { Fraction at } 0.9 \mathrm{M}-\text { and } 1.8 \mathrm{M}- \\
\text { sucrose interface } \\
(\%)\end{array}$ & $\begin{array}{c}\text { Pellet } \\
(\%)\end{array}$ \\
\hline 15 & 29 & 3 & 68 \\
30 & 70 & 2 & 28 \\
60 & 81 & 6 & 13 \\
\hline
\end{tabular}

Bull semen $\left(5 \mathrm{ml}: 8 \times 10^{7}\right.$ spermatozoa $/ \mathrm{ml}$ ) was washed three times in wash buffer and resuspended in $2.5 \mathrm{ml}$ of $0.25 \mathrm{M}$-sucrose in $0.15 \mathrm{M}-\mathrm{NaCl}, 0.01 \mathrm{M}$-tris, $\mathrm{pH} \mathrm{7.9}$. The sample was sonicated for either 15,30 or $60 \mathrm{sec}$ and $1 \mathrm{ml}$ was layered over a discontinuous gradient of $5 \mathrm{ml} 0.9 \mathrm{M}$-sucrose and $5 \mathrm{ml}$ $1.8 \mathrm{M}$-sucrose (dissolved in wash buffer). The gradient was centrifuged at $13,000 \mathrm{~g}$ for $30 \mathrm{~min}$ and fractionated. Sperm heads and intact spermatozoa sedimented; tails were found at the interface between the $0.9 \mathrm{M}$ - and $1.8 \mathrm{M}$-sucrose layers, and soluble enzyme was at the top of the gradient. Control experiments demonstrated no increased activity when the soluble enzyme fraction was sonicated. The results are expressed as a $\%$ of total recovered activity. At least $90 \%$ of the loaded activity was recovered. The original activities placed on the gradients were $21,000 \mathrm{ct} / \mathrm{min}\left[{ }^{3} \mathrm{H}\right] \mathrm{TMP}$ incorporated $/ \mathrm{ml}$ for 15 $\mathrm{sec}$ sonication, $43,340 \mathrm{ct} / \mathrm{min}\left[{ }^{3} \mathrm{H}\right] \mathrm{TMP}$ incorporated $/ \mathrm{ml}$ for $30 \mathrm{sec}$ sonication, and $78,820 \mathrm{ct} / \mathrm{min}$ $\left[{ }^{3} \mathrm{H}\right] \mathrm{TMP}$ incorporated $/ \mathrm{ml}$ for $60 \mathrm{sec}$ sonication.

inhibition of DNA polymerases from three different bovine sources-spermatozoa, liver mitochondria, and liver nuclei. The latter activity is the chromatinbound DNA polymerase of mol. wt 45,000 found in most eucaryotic cells (Chang \& Bollum, 1971; Chang, 1973). As seen in Table 1, sperm and mitochondrial DNA polymerases are inhibited similarly and more markedly than the low molecular weight DNA polymerase which is only partly inhibited under identical conditions.

Location. A modification of the sucrose gradient procedure of Stambaugh \& Buckley (1969) was used in an attempt to determine the subcellular location of the sperm DNA polymerase activity. Unmasking of DNA polymerase activity in sperm homogenates, as well as its release into the supernatant, required appreciable sonication (Table 2) although the activity, once released, was in a soluble form (Text-fig. 4). The activity is likely, therefore, to be sequestered within some organelle (see 'Discussion'), but attempts to locate the relevant site in the spermatozoa have so far proved unsuccessful.

\section{DISCUSSION}

We believe the DNA polymerase described in this communication is of sperm origin and not present because of contaminating cells for the following reasons: (1) microscopic examination of spermatozoa that were washed and centrifuged through $1.8 \mathrm{M}$-sucrose revealed less than $1 \%$ contaminating cells, (2) every other cell type we have investigated from mouse or bull contains multiple DNA polymerases distinguishable by phosphocellulose, gel filtration, and sucrose gradient centrifugation (N. B. Hecht, unpublished observations; Hecht, 1973; Hecht \& Davidson, 1973), and (3) the activity reported here is more difficult to solubilize than those from other cell sources.

The conditions needed to stabilize the DNA polymerase from bovine spermatozoa merit discussion. Ethylene glycol and trypsin inhibitor are essential for reproducible enzyme extraction. Polyglycols are routinely used to stabilize DNA polymerase activities (Calvin et al., 1967; Loeb, 1969; Sedwick et al., 
1972). The rôle of trypsin inhibitor for this stabilization is uncertain although it probably serves to inactivate any trypsin-like activity released by sonication.

Several DNA polymerases have been reported from many different types of mammalian cells (Weissbach, Shelabach, Fridlender \& Bolden, 1971; Sedwick et al., 1972; Baril, Brown, Jenkins \& Laszlo, 1971). Calvin et al. (1967) have characterized a DNA polymerase activity from rat testis, and Katz \& Hecht (1973), Hecht (1973) and Hecht \& Davidson (1973) have previously reported the existence of several DNA polymerase activities in mouse testis. The multiple activities from mouse testis are distinguishable by differences in molecular weight, physical properties and in their response to salt. Using aqueous subcellular fractionation procedures, the mouse testis nuclei contain a low molecular weight DNA polymerase, the cytosol contains at least two high molecular weight DNA polymerases, and a fourth distinct activity is isolated from the mitochondrial fraction of the cells. Recent studies indicate that bovine testis contains activities similar to those found in mouse (N.B. Hecht, unpublished observations).

The chromatin-bound low molecular weight mouse DNA polymerase has an estimated mol. wt of 50,000 to 60,000 and a sedimentation coefficient of $3 \cdot 5 \mathrm{~S}$, while the soluble high molecular weight DNA polymerases have estimated mol. wts over 100,000 and sedimentation coefficients of 6 to $8 \mathrm{~S}$. By contrast, the mouse mitochondrial DNA polymerase has an estimated mol. wt of 140 to 150,000 and a sedimentation coefficient of $9 \cdot 1 \mathrm{~S}$ for the main peak with a shoulder at approximately $10.5 \mathrm{~S}$. Furthermore, the mitochondrial enzyme is stimulated by $0.15 \mathrm{M}-\mathrm{NaCl}$, a property of several other mitochondrial DNA polymerases (Meyer \& Simpson, 1968; Kalf \& Ch'ih, 1968).

The sperm DNA polymerase has an estimated mol. wt of 150,000 , a sedimentation coefficient of $8.8 \mathrm{~S}$ with a heavier shoulder, is stimulated by $0.15 \mathrm{M}$ to $0.17 \mathrm{~m}$ salt, and is inhibited by ethidium bromide to the same extent as bovine liver mitochondrial DNA polymerase. This evidence reveals a similarity between sperm and mitochondrial DNA polymerases and suggests that mitochondria may be the source of this enzyme activity. Two types of subcellular fractionation methods for spermatozoa have been attempted to reveal the 'in-vivo' location of this polymerase. The sonication procedure of Stambaugh \& Buckley (1969) indicates the activity is either a soluble enzyme or, more probably, is released by the sonication conditions. The trypsin digestion procedure of Millette, Spear, Gall \& Edelman (1973) has not allowed good enzyme recoveries. Isolation of purified sperm mitochondria may aid efforts to determine the cellular location of this activity.

There are a few reports that suggest the occurrence of DNA synthesis in mature spermatozoa. Malkin (1953) has reported the incorporation of radioactive glycine and adenine into the DNA of mature sea urchin spermatozoa and Salisbury \& Hart (1970) have speculated that the radioactivity they find incorporated into the DNA in the sperm head may represent a true metabolic turnover. The relationship between these DNA syntheses and the reported sperm DNA polymerase is unknown.

This communication is the first to describe a DNA polymerase activity from mature spermatozoa. The fact that the multiple DNA polymerases found 
in most mammalian cells are not found in spermatozoa suggests that the testicular DNA polymerase activities are not distributed equally in all the testis cells. Further studies are in progress to delineate the quantitative and qualitative aspects of DNA polymerase in the differentiating testis cells.

\section{ACKNOWLEDGMENTS}

This research was supported by U.S.P.H.S. Grant No. HD05651. Bull semen was most generously supplied by Eastern Artificial Insemination Cooperative of Ithaca, New York. It is a pleasure to acknowledge the expert technical assistance of Donna Davidson. I thank Dr E. Siegel, Dr S. Slapikoff and Dr M. Zeldin for valuable discussions and a critical reading of this manuscript.

\section{REFERENGES}

ANDREws, P. (1965) The gel filtration behaviour of proteins related to their molecular weights over a wide range. Biochem. J. 96, 595.

Aposhian, H. V. \& Kornberg, A. (1962) Enzymatic synthesis of deoxyribonucleic acid. f. biol. Chem. 237,519 .

Baril, E. F., Brown, O. E., Jenkins, M. D. \& Laszlo, J. (1971) DNA polymerase with rat liver ribosomes and smooth membranes. Purification and properties of the enzymes. Biochemistry, $10,198$.

Burgess, R. R. (1969) A new method for the large scale purification of E. coli DNA-dependent RNA polymerase. 7. biol. Chem. 244, 6160 .

Galvin, H. I., Kosto, B. \& Williams-Ashman, H. G. (1967) Enzymic incorporation of deoxyribonucleosides into DNA in mammalian testis. Archs Biochem. Biophys. 118, 670.

Chang, L. M. S. (1973) Low molecular weight DNA polymerase from calf thymus chromatin. $\mathcal{F}$. biol. Chem. 248, 3789.

Ghang, L. M. S. \& Bollum, F. J. (1971) Low molecular weight DNA polymerase in mammalian cells. F. biol. Chem. 246, 5835.

Clermont, Y. \& Leblond, C. P. (1953). Renewal of spermatogonia in the rat. Am. F. Anat. 93, 475.

Clermont, Y. \& Perey, B. (1957) Quantitative study of the cell population of the seminiferous tubules in immature rats. Am. J. Anat. 100, 241.

HECHT, N. B. (1973) Interconvertibility of mouse DNA polymerase activities derived from the nucleus and cytoplasm. Biochim. biophys. Acta, 312, 471.

Heснт, N. B. \& Davidson, D. (1973) The presence of a common active subunit in low and high molecular weight murine DNA polymerases. Biochem. biophys. Res. Commun. 51, 299.

KALF, G. F. \& CH'IH, J. J. (1968) Purification and properties of DNA polymerase from rat liver mitochondria. 7. biol. Chem. 243, 4904.

Katz, S. E. \& HEcht, N. B. (1973) A rapid technique to resolve and partially purify multiple DNA polymerases from a crude extract. Analyt. Biochem. 53, 441.

Kzotz, I. M. \& Darnall, D. W. (1969) Protein subunits : a table. 2nd edn. Science, N. $\Upsilon$. 166, 126.

LOEB, L. A. (1969) Purification and properties of DNA polymerase from nuclei of sea urchin embryos. 7. biol. Chem. 244, 1672.

MALKIN, H. M. (1953) Incorporation of glycine $2-{ }^{14} \mathrm{C}$ and adenine $4,6-{ }^{14} \mathrm{C}$ into the DNA of mature sea urchin sperm. Biochim. biophys. Acta, 12, 585 .

Martin, R. G. \& AmEs, B. M. (1961) A method for determining the sedimentation behavior of enzymes. J. biol. Chem. 236, 1372.

Meyer, R. R. \& Simpson, M. V. (1968) DNA biosynthesis in mitochondria. Proc. natn. Acad. Sci. U.S.A. 61,130 .

Millette, C. F., Spear, P. G., Gall, W. E. \& Edelman, G. M. (1973) Chemical dissection of mammalian spermatozoa. 7. Cell Biol. 58, 662.

OAKBERG, E. F. (1956) A description of spermiogenesis in the mouse and its use in analysis of the cycle of the seminiferous epithelium and germ cell renewal. Am. F. Anat. 99, 391.

OAKBERG, E. F. (1957) Duration of spermatogenesis in the mouse and timing of stages of the cycle of the seminiferous epithelium. Am. 7. Anat. 99, 507.

Salisbury, G. W. \& HART, R. G. (1970) Gamete aging and its consequences. Biol. Reprod., Suppl. 2, 1. 
Sedwick, W. D., Wang, T. S. \& Korn, D. (1972) Purification and properties of nuclear and cytoplasmic DNA polymerases from human KB cells. J. biol. Chem. 247, 5026.

Stambaugh, R. \& Buckley, J. (1969) Identification and subcellular localization of the enzymes effecting penetration of the zona pellucida by rabbit spermatozoa. F. Reprod. Fert. 19, 423.

Weissbach, A., Shelabach, A. Fridlender, B. \& Bolden, A. (1971) DNA polymerases from human cells. Nature, New Biol. 231, 167. 